Omar S Rahawi

BDS, MSc ( Assist Lect)

\section{The effect of colored drinks on the surface hardness of composite resin.}

\author{
Dept. of Conservative dentistry \\ College of Dentistry, University of Mosul
}

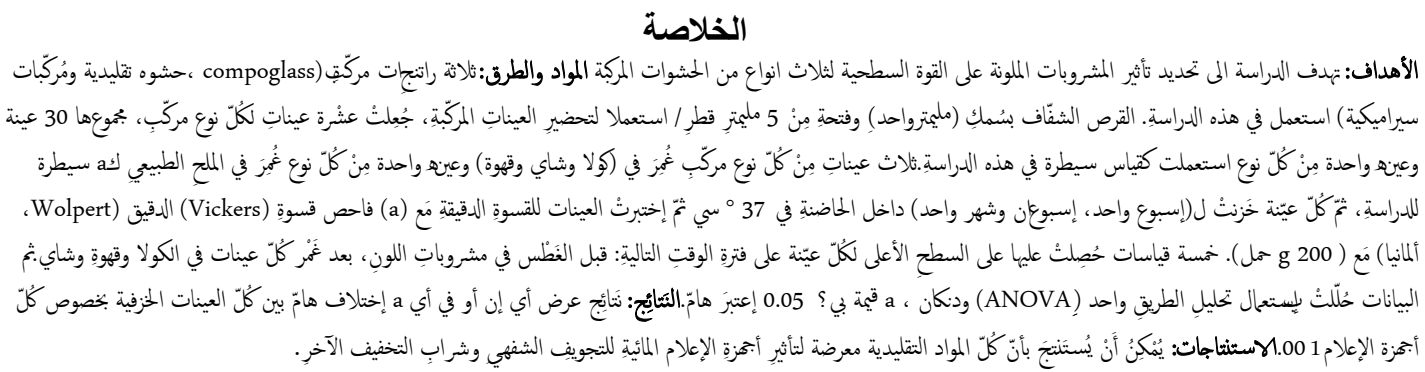

ABSTRACT

Aims: to determine the effect of colored drinks on the surface hardness of three types of composite restorations. Materials \& methods: Three composite resins (a compoglass, conventional and ceramic composites) were used in this study. Transparent disc with $2 \mathrm{~mm}$ thickness and hole of $5 \mathrm{~mm}$ diameter were used for the preparation of composite samples, ten samples were made for each type of composite with a total of 30 samples. Four samples from each type of composite were immersed in ( a cola ,tea, normal saline and coffee) respectively (normal saline as a control for the study), after that each colored drink measure amount of ph before put the samples using ph meter( $\mathrm{Pw} 9421$,philips) and then each sample stored for (one week, two week and one month) inside incubator at $37^{\circ} \mathrm{C}$ then the samples were tested for the micro hardness with a Vickers micro hardness tester(Wolpert,Germany)with $200 \mathrm{~g}$ load. Five micro hardness measurements were obtained on top surface of each sample on the following time period: before immersing in color drinks, after immersing each samples in cola, coffee and tea. Data were analyzed using One way analysis (ANOVA) and Duncan, a value of $\mathrm{P} \leq 0.05$ was considered significant .Results: The results of ANOVA showing a significant difference among all ceramic samples regarding all media and time when $\mathrm{P} \leq 0.05$. Conclusion: it can be concluded that all conventional materials are susceptible to the effect of aqueous media of oral cavity and other softening drink. Keywords: micro hardness, colored drinks, composite restoration.

Rahawi OS. The effect of colored drinks on the surface hardness of composite resin. Al-Rafidain Dent J. 2010; 10(2):322 - 331 .

Received: $13 / 5 / 2009$

Sent to Referees: $18 / 5 / 2009$

Accepted for Publication: 22/7/2009

\section{INTRODUCTION}

Composite resins are widely used in restorative dentistry, there are number of reason other than dental caries why the tooth may require repair or restoration they include erosion ,trauma ,abrasion and aesthetically defect teeth. The role of diet in the etiology of dental erosion has received the most attention paid to colored drink. ${ }^{(1)}$.

Restorative filling material used in dentistry are required to have long - term durability in the oral cavity this is a complex environment where the material is in contact with saliva, a fluid that contain a variety of inorganic and organic species ,together with flora complex ${ }^{(2)}$.

One of the most important physical properties of restorative filling material is surface micro hardness which correlates well to compressive strength and abrasion resistance ${ }^{(3)}$.

The attractiveness of tooth -colored restoration has stimulated research in this particular area of operative dentistry during recent year. Patients are increasing demanding esthetic restoration not only in the anterior region but also for posterior teeth $^{(4)}$. 
Various glass ionomer and composites have been used clinically because of their beneficial properties, such as adhesion to enamel and dentin and fluoride release . However ,problems associated with these restorative material have also demonstrated these restorative are continually bathed in saliva ,and water absorption for some material is inevitable ${ }^{(5)}$.

Although conventional material are routinely used in clinic ,their mechanical properties including hardness have not widely investigate .

Hardness is defined as the resistance of material to a permanent indentation and its ability to abrade opposing dental structures ${ }^{(6)}$.

Among the properties related to hardness of material are strength, proportional limit and ductility .one in vitro study reported that bis-acrylic resin composite materials were harder than methyl methacrylate resin, the apparent difference may be attributed in part to the effects of intra-oral dietary solvents, the resin matrix of dental composites are softened by organic acids and various food and liquid constituent. Leaching of composite filler and integration of the filler -resin interface(silane coupling agent) can also occur under oral condition ,the aforementioned could contribute to the softening of bis-acryl resin composite intra-orally ${ }^{(7)}$.

\section{MATERIALS AND METHODS}

Three clinically used esthetic restorative materials: ceramic composite (Tetraceram, ivoclar,vevadent), conventional composite (technology general, TG ), and compoglass (technology general,TG ), which are commonly used categories of the esthetic restorative materials.

For the preparation of samples, the color A2 was used for every material. Transparent discs with $2 \mathrm{~mm}$ thickness and a hole of $5 \mathrm{~mm}$ diameter were used for the production of composite samples. The discs were positioned on a transparent celluloid matrix strip laying on a glass slab. After insertion of the material into the discs incrementally using plastic instrument, another strip was put over them and pressed tightly over the discs in order to obtain flat sample surface. Then each samples was cured using a halogen curing unit (hangzhou A.L.S. dental appliance CO.LTD) for 40 second, with the tip of light cure is in contact with the samples ( nearly to touch), each samples were placed in a plastic mold filled with acrylic resin ( cold cure), were the samples place on the center of plastic molds.

Ten samples were made for each type of composite restoration, four samples from each type of composite were immersed in( a cola ,tea, normal saline and coffee) respectively within three period of time (one week, two weeks and one month)( the normal saline as a control for this study), then all samples were stored inside incubator at $37 \mathrm{C}^{\mathrm{o}}$, then after that the colored drinks were prepared according to the conventional natural procedure 10 gram from black tea and coffee in $100 \mathrm{ml}$ of water boiling not more than 5 minutes while the cola drink was readymade, after that for each type of drinks put inside ph meter( $\mathrm{Pw}$ 9421, philips) to measure amount of ph before immersing the samples the reading was obtain as the following ( coffee 6.9, tea 6.5.and cola 5.5), then for each period of time the samples were taken for micro hardness measurements, with each period of time the drinks were replace with a new one and ph were measured before replacing the drinks, Vickers micro hardness tester (Wolpert, Germany) was used, with a $200 \mathrm{~g}$ load. Five micro hardness measurements were taken on the top of each samples (samples that immersed in normal saline for control, samples that immersed inside Cola , samples that immersed in coffee, samples that immersed inside tea) for each periods of time ( one week, two week and one month).

\section{RESULT}

Results for surface hardness determinations are shown in tables1-8.

Table (1) show one way ANOVA, Descriptive analysis and Duncan multiple way range for Ceramic regarding all medias and time. According to analysis of variance ANOVA Table (1) a statistically significant effect on micro hardness of ceramic restoration regarding media and time. 
Table (1): one way ANOVA, Descriptive analysis and Duncan multiple way range for Ceramic regarding all medias and Time.

\begin{tabular}{|c|c|c|c|c|c|c|c|c|}
\hline$A N O V A$ & Sum of sq & ares & & df & Mean & quare & $\mathrm{F}$ & Sig. \\
\hline Between groups & 332.700 & & & 9 & 63.96 & & 16.552 & .000 \\
\hline within groups & 44.667 & & & 20 & 2.233 & & & \\
\hline Total & 377.367 & & & 29 & & & & \\
\hline DESCRIPTIVE & Variables & $\mathrm{N}$ & Minimum & \multicolumn{2}{|c|}{ Maximum } & SD & Mean $^{*} \pm$ SE & $\begin{array}{l}\text { Duncan } \\
\text { Groups ** }\end{array}$ \\
\hline \multirow{10}{*}{ 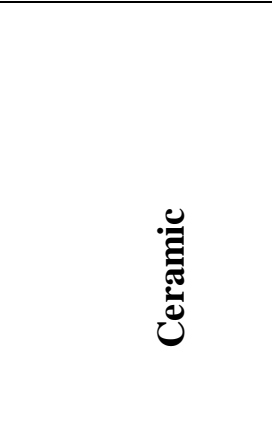 } & V1 & 5 & 78 & \multicolumn{2}{|c|}{82} & 2.00 & $80 \pm 1.15$ & $\mathrm{~A}$ \\
\hline & V4 & 5 & 78 & \multicolumn{2}{|l|}{80} & 1.00 & $79 \pm 0.57$ & A \\
\hline & V7 & 5 & 75 & \multicolumn{2}{|c|}{77} & 1.00 & $76 \pm 0.58$ & B \\
\hline & V10 & 5 & 78 & \multicolumn{2}{|c|}{76} & 1.00 & $75 \pm 0.57$ & B \\
\hline & V13 & 5 & 75 & \multicolumn{2}{|l|}{77} & 1.00 & $76 \pm 0.57$ & B \\
\hline & V16 & 5 & 74 & \multicolumn{2}{|c|}{76} & 1.00 & $75 \pm 0.57$ & B \\
\hline & V 19 & 5 & 68 & \multicolumn{2}{|l|}{71} & 1.52 & $69 \pm 0.88$ & $\mathrm{D}$ \\
\hline & $\mathrm{V} 22$ & 5 & 72 & \multicolumn{2}{|l|}{75} & 1.52 & $73 \pm 0.88$ & $\mathrm{BC}$ \\
\hline & V25 & 5 & 70 & \multicolumn{2}{|l|}{73} & 1.52 & $71 \pm 0.88$ & CD \\
\hline & V 28 & 5 & 67 & \multicolumn{2}{|l|}{72} & 2.51 & $69 \pm 1.45$ & D \\
\hline
\end{tabular}

${ }^{\text {* }}$ Mean unit in gram measurement. ${ }^{* *}$ Different letter mean significant difference at $\mathrm{P} \leq 0.05$

This table showed a highest hardness occur in control group (V1, ceramic) and the lowest hardness occur in coffee media in two week and one month from immersion period (V25,V28,ceramic in coffee two weeks and one month) respectively and the other variable lying in between these range. Table (2): one way ANOVA, Descriptive analysis and Duncan multiple range for compoglass regarding all medias, this table show the statistically significant effect on micro hardness regarding all media and time. this table show highest hardness for second variable (compoglass) occur in control group (V2, compoglass )and the lowest occur in two week and one month from immersion period (V 26, V 29 compoglass in coffee in two weeks and one month). 
Table (2): one way ANOVA, Descriptive analysis and Duncan multiple way range for compoglass regarding all medias and Time.

\begin{tabular}{|c|c|c|c|c|c|c|c|}
\hline$A N O V A$ & \multicolumn{3}{|c|}{ Sum of squares } & $\mathrm{df}$ & $\begin{array}{c}\text { Mean } \\
\text { Square }\end{array}$ & $\mathrm{F}$ & Sig. \\
\hline $\begin{array}{l}\text { Between } \\
\text { groups }\end{array}$ & \multicolumn{3}{|c|}{943.367} & 9 & 63.967 & 53.298 & .000 \\
\hline within groups & \multicolumn{3}{|c|}{39.333} & 20 & 2.233 & & \\
\hline Total & \multicolumn{3}{|c|}{982.700} & 29 & & & \\
\hline DESCRIPTIVE & Variables & $\mathrm{N}$ & Minimum & Maximum & SD & Mean $^{*} \pm \mathrm{SE}$ & $\begin{array}{l}\text { Duncan } \\
\text { Groups ** }\end{array}$ \\
\hline \multirow{10}{*}{ 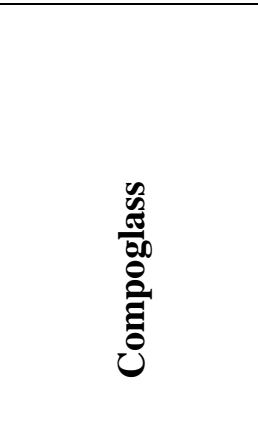 } & V2 & 5 & 88 & 93 & 2.51 & $90 \pm 1.45$ & $\mathrm{~A}$ \\
\hline & V5 & 5 & 77 & 80 & 1.52 & $78 \pm 0.88$ & B \\
\hline & V8 & 5 & 75 & 77 & 1.00 & $76 \pm 0.57$ & $\mathrm{BC}$ \\
\hline & V11 & 5 & 73 & 75 & 1.00 & $74 \pm 0.57$ & DC \\
\hline & V14 & 5 & 73 & 75 & 1.00 & $74 \pm 0.58$ & DC \\
\hline & V17 & 5 & 72 & 74 & 1.00 & $73 \pm 0.57$ & D \\
\hline & V20 & 5 & 69 & 71 & 1.00 & $70 \pm 0.58$ & $\mathrm{E}$ \\
\hline & $\mathrm{V} 23$ & 5 & 77 & 79 & 1.00 & $78 \pm 0.57$ & $\mathrm{BC}$ \\
\hline & V26 & 5 & 74 & 76 & 1.00 & $75 \pm 0.57$ & DC \\
\hline & V29 & 5 & 68 & 72 & 2.00 & $70 \pm 1.15$ & $\mathrm{E}$ \\
\hline
\end{tabular}

* Mean unit in gram measurement. ** Different letter mean significant difference at $\mathrm{P} \leq 0.05$

Table (3): one way ANOVA, Descriptive analysis and Duncan multiple way range for conventional composite regarding all medias and Time. the result shows show the statistically significant effect on micro hardness. This table show the highest value also occur in control group (V3, conventional composite ) and lowest value also occur in second week and one month from immersion period (V 27, (V 30, conventional composite in coffee for two weeks and one month ) respectively and other variable lying in between these range. 
Table (3): one way ANOVA, Descriptive analysis and Duncan multiple way range for conventional composite regarding all medias and Time.

\begin{tabular}{|c|c|c|c|c|c|c|c|c|c|}
\hline ANOVA & \multicolumn{3}{|c|}{ Sum of squares } & $\mathrm{d}$ & $\mathrm{Me}$ & $\mathrm{Squ}$ & are & & Sig. \\
\hline Between groups & \multicolumn{3}{|c|}{1102.533} & 9 & & 2.50 & \multicolumn{2}{|c|}{59.276} & .000 \\
\hline within groups & \multicolumn{3}{|c|}{41.333} & 20 & & .067 & & & \\
\hline Total & \multicolumn{3}{|c|}{1143.867} & 29 & & & & & \\
\hline \multirow[t]{11}{*}{ DESCRIPTIVE } & Variables & $\mathrm{N}$ & Minimum & & um & SD & Mean $^{*} \pm \mathrm{SE}$ & \multicolumn{2}{|c|}{$\begin{array}{l}\text { Duncan } \\
\text { Groups** }\end{array}$} \\
\hline & V3 & 5 & 88 & 93 & & 2.51 & $90 \pm 1.45$ & \multicolumn{2}{|l|}{ A } \\
\hline & V6 & 5 & 77 & 80 & & 1.52 & $78 \pm 0.88$ & \multicolumn{2}{|l|}{$\mathrm{B}$} \\
\hline & V9 & 5 & 78 & 80 & & 1.00 & $79 \pm 0.57$ & \multicolumn{2}{|l|}{ B } \\
\hline & V12 & 5 & 72 & 74 & & 1.00 & $73 \pm 0.57$ & \multicolumn{2}{|c|}{$\mathrm{DC}$} \\
\hline & V15 & 5 & 74 & 76 & & 1.00 & $75 \pm 0.58$ & \multicolumn{2}{|c|}{$\mathrm{CB}$} \\
\hline & V18 & 5 & 70 & 73 & & 1.52 & $71 \pm 0.90$ & \multicolumn{2}{|c|}{$\mathrm{DE}$} \\
\hline & V21 & 5 & 69 & 71 & & 1.00 & $70 \pm 0.57$ & \multicolumn{2}{|c|}{$\mathrm{EF}$} \\
\hline & V24 & 5 & 74 & 76 & & 1.00 & $75 \pm 0.58$ & \multicolumn{2}{|l|}{$\mathrm{C}$} \\
\hline & V27 & 5 & 70 & 73 & & 1.52 & $71 \pm 0.88$ & \multicolumn{2}{|c|}{$\mathrm{ED}$} \\
\hline & V30 & 5 & 67 & 70 & & 1.52 & $68 \pm 0.88$ & \multicolumn{2}{|l|}{$\mathrm{F}$} \\
\hline
\end{tabular}

${ }^{*}$ Mean unit in gram measurement. ${ }^{*}$ * Different letter mean significant difference at $\mathrm{P} \leq 0.05$

Table (4): one way ANOVA and Duncan multiple way range for control versus Tea regarding all materials and Time show the mean Vickers hardness values (VHN) regarding all medias and times.

The result show the highest value occur in control group variables (V1, ceram- ic) while the lower values occur in following variables (V12, V11, V10, conventional composite, compoglass, ceramic) respectively after one month from immersion period, and other variable lying in between these range. 
Table (4): one way ANOVA and Duncan multiple way range for control versus Tea regarding all materials and Time.

\begin{tabular}{|c|c|c|c|c|c|c|}
\hline ANOVA & \multicolumn{2}{|c|}{ Sum of squares } & df & Mean Square & $\mathrm{F}$ & Sig. \\
\hline Between groups & \multicolumn{2}{|c|}{1106.333} & 11 & 100.576 & 42.5976 & .000 \\
\hline within groups & \multicolumn{2}{|c|}{56.667} & 24 & 2.361 & & \\
\hline Total & \multicolumn{2}{|c|}{1163.000} & 35 & & & \\
\hline DUNCANANALYSIS & Variables & $\mathrm{N}$ & \multicolumn{2}{|c|}{ Mean* ${ }^{*}$ SE } & \multicolumn{2}{|c|}{ Duncan Groups ** } \\
\hline \multirow{12}{*}{ 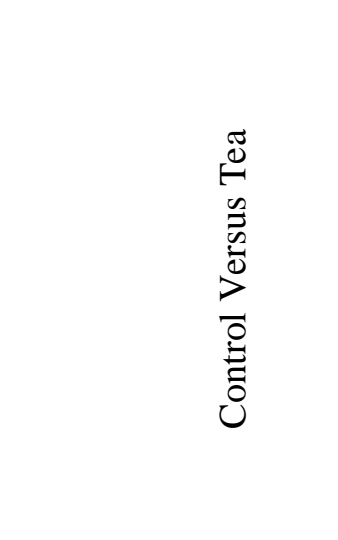 } & V1 & 5 & \multicolumn{2}{|c|}{$80 \pm 1.15$} & \multicolumn{2}{|c|}{$\mathrm{B}$} \\
\hline & V2 & 5 & \multicolumn{2}{|c|}{$90 \pm 1.45$} & \multicolumn{2}{|c|}{ A } \\
\hline & V3 & 5 & \multicolumn{2}{|c|}{$90 \pm 1.45$} & \multicolumn{2}{|c|}{ A } \\
\hline & V4 & 5 & \multicolumn{2}{|c|}{$79 \pm 0.57$} & \multicolumn{2}{|c|}{ B } \\
\hline & V5 & 5 & \multicolumn{2}{|c|}{$78 \pm 0.88$} & \multicolumn{2}{|c|}{$\mathrm{BC}$} \\
\hline & V6 & 5 & \multicolumn{2}{|c|}{$78 \pm 0.88$} & \multicolumn{2}{|c|}{$\mathrm{BC}$} \\
\hline & V7 & 5 & \multicolumn{2}{|c|}{$76 \pm 0.57$} & \multicolumn{2}{|c|}{ DC } \\
\hline & V8 & 5 & \multicolumn{2}{|c|}{$76 \pm 0.57$} & \multicolumn{2}{|c|}{$\mathrm{DC}$} \\
\hline & V9 & 5 & \multicolumn{2}{|c|}{$79 \pm 0.58$} & \multicolumn{2}{|c|}{$\mathrm{B}$} \\
\hline & V10 & 5 & \multirow{2}{*}{\multicolumn{2}{|c|}{$\begin{array}{l}75 \pm 0.57 \\
74 \pm 0.58\end{array}$}} & \multicolumn{2}{|c|}{ ED } \\
\hline & V11 & 5 & & $\begin{array}{r}74 \pm 0.58 \\
73+0.57\end{array}$ & \multirow{2}{*}{\multicolumn{2}{|c|}{$\mathrm{ED}$}} \\
\hline & V12 & 5 & $73 \pm$ & .57 & & \\
\hline
\end{tabular}

* Mean unit in gram measurement. ** Different letter mean significant difference at $\mathrm{P} \leq 0.05$

Table (5): one way ANOVA and Duncan multiple way range for control versus Cola regarding all materials and Time .the result show the highest value occur in control group variables ( V1 ceramic,) while the lower values occur in following variables (V21,conventional composite in cola one month)(V20,compoglass in cola one month)(V19,ceramic in cola one month)(V18,compoglass in cola one month) respectively after one month from immersion period, and other variable lying in between these range.

Table (5): one way ANOVA and Duncan multiple way range for control versus Cola regarding all materials and Time.

\begin{tabular}{|c|c|c|c|c|c|}
\hline \multirow{3}{*}{$\begin{array}{l}\text { ANOVA } \\
\text { Between groups } \\
\text { within groups }\end{array}$} & Sum of squares & \multirow{2}{*}{$\begin{array}{l}\text { Df } \\
11\end{array}$} & \multirow{2}{*}{$\frac{\text { Mean Square }}{161.179}$} & \multirow{2}{*}{$\begin{array}{l}\mathrm{F} \\
68.264\end{array}$} & \multirow{2}{*}{$\begin{array}{l}\text { Sig. } \\
.000\end{array}$} \\
\hline & 1772.972 & & & & \\
\hline & 56.667 & 24 & 2.361 & & \\
\hline Total & 1829.639 & 35 & & & \\
\hline \multirow[t]{12}{*}{ DUNCANANALYSIS } & Variables & \multicolumn{2}{|c|}{$\pm \mathrm{SE}^{*}$ Mean } & \multicolumn{2}{|c|}{$\begin{array}{l}\text { Duncan } \\
\text { Groups** }\end{array}$} \\
\hline & V1 & \multicolumn{2}{|c|}{$80 \pm 1.15$} & \\
\hline & V2 & \multicolumn{2}{|c|}{$90 \pm 1.45$} & \multicolumn{2}{|l|}{ A } \\
\hline & V3 & \multicolumn{2}{|c|}{$90 \pm 1.45$} & \multicolumn{2}{|l|}{ A } \\
\hline & V13 & \multicolumn{2}{|c|}{$76 \pm 0.57$} & \multicolumn{2}{|l|}{$\mathrm{C}$} \\
\hline & V14 & \multicolumn{2}{|c|}{$74 \pm 0.57$} & \multicolumn{2}{|c|}{ ED } \\
\hline & V15 & \multicolumn{2}{|c|}{$\begin{array}{l}75 \pm 0.58 \\
75+0.57\end{array}$} & \multicolumn{2}{|c|}{$\mathrm{DC}$} \\
\hline & V16 & \multicolumn{2}{|c|}{$75 \pm 0.57$} & \multicolumn{2}{|c|}{ DC } \\
\hline & V17 & \multicolumn{2}{|c|}{$73 \pm 0.58$} & \multicolumn{2}{|c|}{ ED } \\
\hline & V18 & \multirow{2}{*}{\multicolumn{2}{|c|}{$\begin{array}{l}71 \pm 0.88 \\
69+0.88\end{array}$}} & \multicolumn{2}{|c|}{ FE } \\
\hline & V19 & & & \multicolumn{2}{|l|}{$\mathrm{F}$} \\
\hline & V20 & \multicolumn{2}{|c|}{$70 \pm 0.57$} & \multicolumn{2}{|l|}{$\mathrm{F}$} \\
\hline
\end{tabular}

*Mean unit in gram measurement. **Different letter mean significant difference at $\mathrm{P} \leq 0.05$ 
Table (6): one way ANOVA and Duncan multiple way range for control versus Coffee regarding all materials and Time, the result show the highest value occur in control group variables ( V1 ceramic,,) while the lower values occur in following variables (V30, conventional composite in coffee one month),(V29, compoglass in coffee one month),(V28 ceramic in coffee one month),(V27, compoglass in coffee two weeks) respectively after one month from immersion period, and other variable lying in between these range.

Table (6): one way ANOVA and Duncan multiple way range for control versus Coffee regarding all materials and Time.

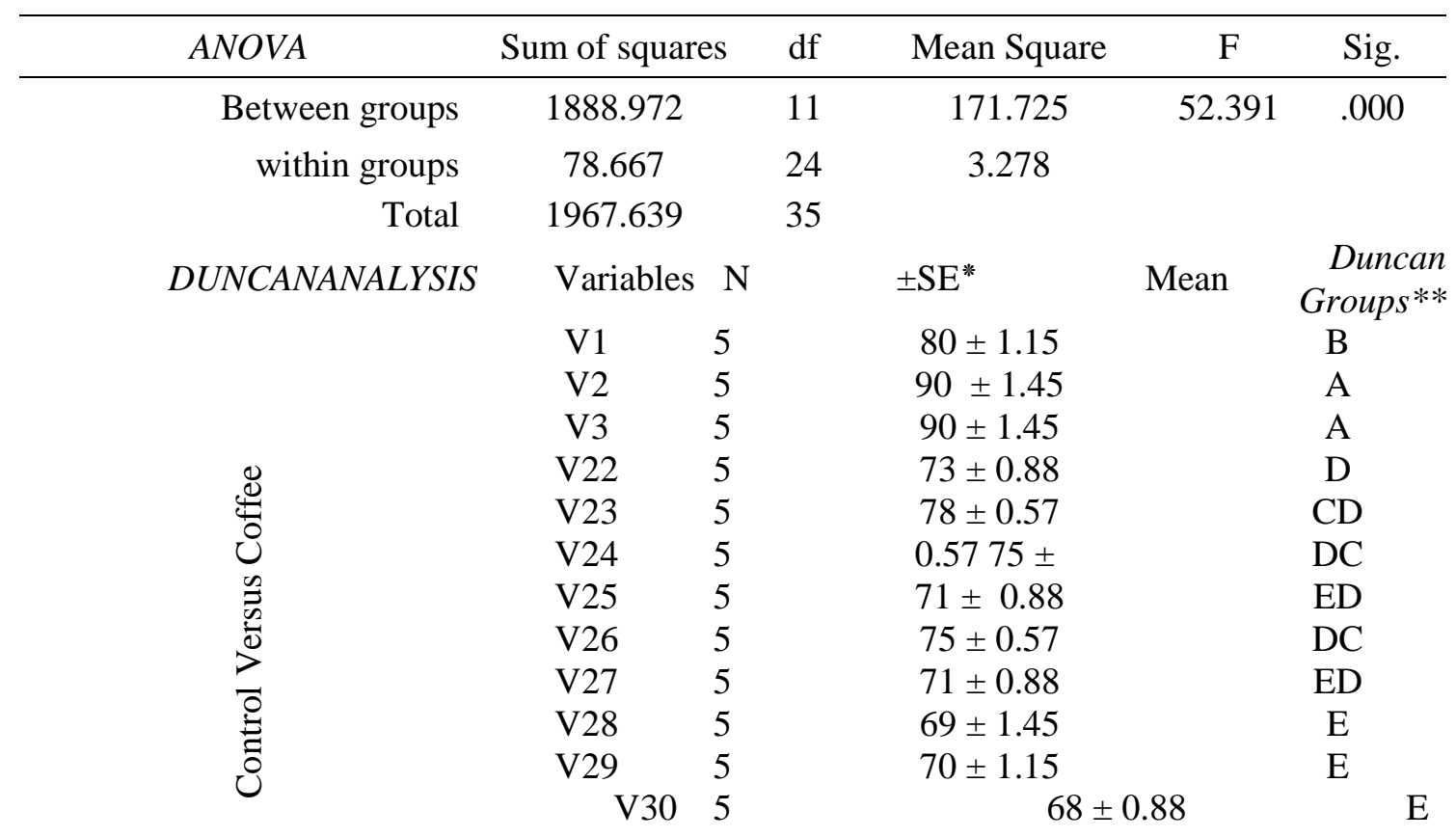

*Mean unit in gram measurement. **Different letter mean significant difference at $\mathrm{P} \leq 0.05$

Table (7): one way ANOVA and Duncan multiple way range for control samples regarding all materials. The highest value occur in control group variables (V1 and V2)(ceramic and compoglass) while the lower values occur in variable (V3,composite). 
Table (7): one way ANOVA and Duncan multiple way range for control samples regarding all materials.

\begin{tabular}{|c|c|c|c|c|c|c|}
\hline ANOVA & Sum of squares & $\mathrm{df}$ & Mean Square & & $\mathrm{F}$ & Sig. \\
\hline Between groups & 227.556 & 2 & 113.778 & & 20.480 & .000 \\
\hline within groups & 33.333 & 6 & 5.556 & & & \\
\hline Total & 260.886 & \multicolumn{5}{|l|}{8} \\
\hline DUNCANANALYSIS & Variables $\mathrm{N}$ & \multirow{2}{*}{\multicolumn{2}{|c|}{$\begin{array}{l} \pm \mathrm{SE}^{*} \\
80 \pm 1.15\end{array}$}} & \multirow[t]{2}{*}{ Mean } & \multirow{2}{*}{\multicolumn{2}{|c|}{$\begin{array}{c}\text { Duncan Groups** } \\
\text { B }\end{array}$}} \\
\hline Ceramic & V1 & & & & & \\
\hline Compoglass & $\mathrm{V} 2$ & \multicolumn{2}{|c|}{$90 \pm 1.45$} & & \multicolumn{2}{|c|}{ A } \\
\hline Composite & V3 & \multicolumn{3}{|c|}{$90 \pm 1.45$} & \multicolumn{2}{|c|}{ A } \\
\hline
\end{tabular}

*Mean unit in gram measurement. **Different letter mean significant difference at $\mathrm{P} \leq 0.05$.

Table (8): one way ANOVA and Duncan multiple way range for all samples regarding all materials, medias and time. The result show the highest value occur in control group variables ( V2 and V3)( compoglass and composite) while the lower values occur in following variables
(V30,composite in side cola after one month)(V19,ceramic in cola after one month)(V28, ceramic in coffee after one month)( V 20,compoglass in cola after one month)(V 21, composite in cola after one month) (V29, compoglass in coffee after one month).

Table (8): one way ANOVA and Duncan multiple way range for all samples regarding all materials, medias and time.

\begin{tabular}{|c|c|c|c|c|c|c|c|c|}
\hline \multicolumn{2}{|c|}{ ANOVA } & \multicolumn{2}{|c|}{ Sum of squares } & \multirow[t]{2}{*}{ df } & \multicolumn{2}{|c|}{ Mean Square } & \multirow{2}{*}{$\frac{F}{39.706}$} & \multirow{2}{*}{$\frac{\text { Sig. }}{.000}$} \\
\hline \multirow{34}{*}{ 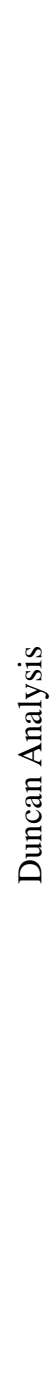 } & Betw & roups & 2405.286 & & 29 & 82.941 & & \\
\hline & & roups & 125.333 & & 60 & 2.089 & & \\
\hline & & Total & 2530.622 & & 89 & & & \\
\hline & Variables & $\mathrm{N}$ & & \pm SE* Mean & & & Dunce & roups** \\
\hline & V3 & 5 & & $90 \pm 1.4530$ & & & A & \\
\hline & V2 & 5 & & $90 \pm 1.4530$ & & & A & \\
\hline & V1 & 5 & & $80 \pm 1.1547$ & & & B & \\
\hline & V9 & 5 & & $79 \pm 0.5774$ & & & B & \\
\hline & V4 & 5 & & $79 \pm 0.5774$ & & & B & \\
\hline & V6 & 5 & & $78 \pm 0.8819$ & & & $\mathrm{BC}$ & \\
\hline & V5 & 5 & & $78 \pm 0.8819$ & & & $\mathrm{BC}$ & \\
\hline & V23 & 5 & & $78 \pm 0.774$ & & & $\mathrm{BC}$ & \\
\hline & V13 & 5 & & $76 \pm 0.5774$ & & & $\mathrm{CD}$ & \\
\hline & V8 & 5 & & $76 \pm 0.5774$ & & & $\mathrm{CD}$ & \\
\hline & V7 & 5 & & $76 \pm 0.5774$ & & & $\mathrm{CD}$ & \\
\hline & V26 & 5 & & $75 \pm 0.5774$ & & & $\mathrm{DE}$ & \\
\hline & V24 & 5 & & $75 \pm 0.5774$ & & & $\mathrm{DE}$ & \\
\hline & V16 & 5 & & $75 \pm 0.5774$ & & & $\mathrm{DE}$ & \\
\hline & V15 & 5 & & $75 \pm 0.5774$ & & & $\mathrm{DE}$ & \\
\hline & V10 & 5 & & $75 \pm 0.5774$ & & & FE & \\
\hline & V14 & 5 & & $74 \pm 0.5774$ & & & FE & \\
\hline & V11 & 5 & & $75 \pm 0.5774$ & & & FE & \\
\hline & V22 & 5 & & $73 \pm 0.8819$ & & & FE & \\
\hline & V17 & 5 & & $73 \pm 0.5447$ & & & FE & \\
\hline & V12 & 5 & & $75 \pm 0.5774$ & & & FG & \\
\hline & V27 & 5 & & $71 \pm 0.8819$ & & & FG & \\
\hline & V25 & 5 & & $75 \pm 0.5774$ & & & FG & \\
\hline & V18 & 5 & & $71 \pm 0.5774$ & & & FG & \\
\hline & V29 & 5 & & $70 \pm 1.1547$ & & & $\mathrm{HG}$ & \\
\hline & V21 & 5 & & $70 \pm 1.1547$ & & & HG & \\
\hline & V20 & 5 & & $70 \pm 1.1547$ & & & HG & \\
\hline & V28 & 5 & & $70 \pm 1.1547$ & & & HG & \\
\hline & V19 & 5 & & $69 \pm 1.4530$ & & & HG & \\
\hline & V30 & 5 & & $69 \pm 0.8819$ & & & $\mathrm{H}$ & \\
\hline
\end{tabular}




\section{DISCUSSION}

The aqueous environment of oral cavity, the low $\mathrm{pH}$ due to cariogenic microorganisms or acidic food, ionic composition and ionic strength of saliva, or enzymatic attacks are important parameters which may influence the physical and mechanical characteristics of the restorative dental materials ${ }^{(8)}$. This study tested the effect of colored drinks on the surface microharedness of esthetic restoration.

According to the result of this present study all the restorative materials shows decrease in their micro hardness from one week of immersion to the one month period this decrease in their micro hardness related to the lowering in $\mathrm{pH}$ number after each period of time until reach to (5.2.,4 and 2.5) for (coffee, tea and cola ) respectively due to the humid and acidic environment that greaterly reduced the surface microharedness of these restorative materials. When microharedness was evaluated different results were obtained irrespective of the materials and media.

For all types of composite materials all samples that immersed in normal saline show no change in their hardness due to change in $\mathrm{Ph}$ value which is slightly alkaline to slightly acidic, when the media more acidic so more reduction in their microharedness, this demonstrate the capability of these materials(normal saline) to buffer external storage media ${ }^{(9)}$.

The descriptive and Duncan analysis for all restorative materials show significant decrease in the hardness occur when the period of time increase related to the solution of coffee, this lowering in hardness occur due to increase the time with lowering in $\mathrm{Ph}$-value of immersing solution.

For comparism of control with tea the result show that the conventional composite and compoglass show high microharedness value than ceramic this related to the composition of each materials ( composite, compoglass and ceramic) it can be seen that bis-acryl resin composite materials contain bifunctional acrylate which cross link to provide increased mechanical strength and resistance to weakening from diatery solvents ${ }^{(10-12)}$.

For all restorative materials their hardness value show decreases in number oc- cur after one month from immersion period due to some material $\mathrm{s}$ can be release either from colored solution or from restorative its self ${ }^{(13,14)}$.

For control versus cola the result show that hardness value decreases in number occur in the second week and after one month from immersion period, coca cola is a popular soft drink with low $\mathrm{Ph}$ and this low $\mathrm{Ph}$ has significant effect on hardness of restorative materials and has destructive effect on high strength restorative materials ${ }^{(15)}$.

These decrease in hardness related to the Coca Cola contain Phosphoric acid this acid behave as promoting dissolution and hence in eroding the materials ${ }^{(16)}$.

Finally regarding all media and time the analysis study shows the most effect time was one month from immersion period, more time so more decreases in $\mathrm{Ph}$ so the media more acidic and more effect on restorations while for coloring drink the most effective one was the Cola due to lowering $\mathrm{Ph}$ value that continues with the increases of time ${ }^{(17)}$.

\section{CONCLUSIONS}

Based on the finding of the present study, it can be concluded that all restorative materials are susceptible to the effect of aqueous media of softening drinks and behave differently in different storage media all these media lowering $\mathrm{Ph}$ value decrease their hardness and effect on physical properties of restoration.

\section{REFERENCES}

1. Valinoti A C, Neves BG, Salva EM, Mia CL. Surface degradation of composite resins by acidic medicines and ph-cycling. $J$ Appl Oral Sci.2008;16:4.

2. Okada K, Tosaki S, Hirota K, Hume WR. surface hardness change of restorative filling materials stored in saliva. $J$ Dent $M a$ ter. 2001; 17:34-39.

3. Adrian UJ, Michael KS, Clement $\mathrm{Pw}$ Influence of dietary simulating solvent on the hardness of provisional restorative materials. J Dent Mater. 2004; 20:370376

4. Filiz K. The weight change of various light -cured restorative materials stored in water. J Contemp Dent Pract.2005; 6:2: 72- 
79.

5. Aliping-Mckenzie $\mathrm{M}$, Linden $\mathrm{R}$ and Nicholsen J. The effect of Coca- Cola and fruit juices on the surface hardness of glassionmers and compomers. J Oral Rehabil. 2004; 31:1046-1052.

6. Salama FS and Browing MP. microhardness of composite -resins after immersion in cola drink. J Den Mater. 2005;4: 9-12.

7. GeurtesnW,Leyhausen G, Garcia-Godoy F. Effect of storage media on the fluoride release and surface microhardness of four polyacid-modified composite resins. $J$ Dent Mater.1999; 15:196-201.

8. Abu-Bakr N, Han L, Okamoto A, Iwaku MG. Evaluation of the surface roughness of compomer by laser scanning Microscopy. J Dent Mater J. 2001; 20:172.

9. Bagheri R, Tyas MJ, Burrow MF. subsurface degradation of resin-based composites. J. Dent. Mater; 23:944-951.

10. Turssi Cp, Hara AT, Serra MC, Rodrigues JR. Effect of storage media upon the surface microhardness of resin-based restorative materials . J Oral Rehabil.2002; 29;864-71.

11. Wongkhantee S, Patanapiradeji V, Maneeut c, Tantbirojn D. Effect of acidic food and drinks on enamel, dentin and tooth- colored filling materials. $J$ Dent.2006 34:214-20.

12. Topcu FT, Sahinkesen G, Yamanel K, Oktay UE, Ersahan S. influence of different drinks on the stability of dental composites. Eur J Dent. 2009;3 (1): 50-56.

13. Croll TP, Nicholson JW. Glass-ionomer cements in pediatric dentistry. Pediatric Dent 2002; 24:423-24.

14. Flavio HB, Aline TB, Gluacia MB Jose R. Hardness and diametral tensile strength of a hybrid composite resin polymerized with different modes and immersed . Dent $\mathrm{Ma}$ ter. 2005; 21:1098-1103.

15. Lussi A, Jaeggi $T$, Zero D. The role of diet in the etiology of dental erosion. $\mathrm{Ca}$ ries Res. 20047; 38: 34-44.

16. Nicholson JW, Amiri MA. The interaction of dental cement with aqueous solution of varying Ph. J Mater Sci. Med. 1999; 9: 459.

17. Cairns AM, Watson M, Creanor SL, Foye $\mathrm{RH}$. The $\mathrm{Ph}$ and titratable acidity of a range of diluting during their potential effect on dental erosion. J Dent.2002; 30:313-317. 